acquired of his ancient and modern tongues. In analytical power and in his sense of form and appreciation of value in literature I have never known an undergraduate who approached him. In the Michaelmas Term of $193^{8}$ we read the Agamemnon and as an essay question in the Christmas Terminal I mentioned several editions of the play and asked for a comparative review of three of them. Ewart responded with an essay on Sidgwick, Verrall and Headlam, that could have taken its place as it stood in a first-class History of Classical Scholarship-the maturest piece of work I ever read in an examination paper.

And what of the might-have-been, si qua fata aspera rupisset? After the Army went over the Rhine he wrote me a letter-which somehow I had expected-telling me of the various careers that seemed to lie open to him on demobilisation, but saying that he was attracted most of all by an academic career in the field of history and politics. I replied suggesting Modern Greats, and asked him to await the answer to a letter I was writing to a friend in Oxford. In that letter I made bold to say that the College which admitted Ewart would in all probability be choosing its future Head. With my friend's reply came the news of Ewart's death.

W. M. Galder.

\title{
DAVID JOHN WALLACE
}

I9I4-I 944 .

David John Wallace, son of Captain the Rt. Hon. David Euan Wallace, was born in I9I4 and educated at Eton and Balliol, where he was president of the Junior Common Room. After taking a first class in Greats, and obtaining a Harmsworth Senior Scholarship at Merton Gollege, he spent two years as a Student of the British School at Athens, and devoted himself to the study of Byzantine art. In $193^{8}$ he surveyed the sites of medieval fortifications in central Greece, the southern Peloponnese, and the Cyclades, and in 1938-39 surveyed the Frankish castles. He married a fellow-student, Miss Prudence Magor.

On the outbreak of war, Wallace served for two years as Press Attaché to the British Legation at Athens, and was evacuated when Greece was invaded in I94I. In July I 943 he returned to Greece as liaison officer with the Greek guerilla forces in Epirus; but after a few months of brilliant military activity he was transferred to an administrative post in Cairo, where his knowledge of Greek politics was of great value. But his heart was with the fighting men, and after a while he was released for service in Greece, and was in continuous active enterprise with the guerilla bands in Epirus.

In August 1944 he took part in an assault by the 3/40th Evzone Regiment, under Lt.-Col. Agoras, on the German fortified post at Menina, between Preveza and Paramythia, covering communications and supplies. The attack reached the fortified houses which encircled the town, and here Wallace was hit and killed immediately by machine-gun fire.

On his tombstone his Greek comrades carved the epitaph: ' The soil of Greece is proud to offer hospitality to this hero.'

Wallace was a fine classical scholar, a keen traveller and explorer, with a wide interest in politics, art and antiquities, deep understanding of Greek people and problems, wide capacity for friendship and leadership, and high diplomatic and military distinction. With striking appearance and slight build he combined, in the words of one who knew him at Merton, ' a queer physical toughness and enduring quality. He looked as if he were meant for the arts, but his real métier was for action, and he found what he wanted.' His work at the School was planned on broad lines, but it is doubtful how much had reached a stage where publication will be possible.

John L. Myres. 